\title{
SKRIV KRONIKK
}

Ved å skrive kronikker kan sykepleiere gi allmennheten innsyni viktige sykepleiefaglige problemstillinger.

Åpner man en avis kan man ikke unngå å se en kronikk, ofte lett synlig plassert. I noen aviser er kronikkspalten plassert i nærheten av lederen til redaktøren, derav det engelske begrepet op-ed loposite editor). Kronikken skrives gjerne av fagfolk som formidler en klar og sterk mening. Mens budskapet ofte har en faglig karakter, er begrepene og språket i en kronikk tilpasset målgruppen man ønsker å nå. I en vanlig avis er det allmennheten, mens kronikker $\mathrm{i}$ fagtidsskrifter er rettet mot tidsskriftets lesergruppe.

\section{> FAGSPøRSMÅL FOR ALLMENNHETEN}

Kronikkforfatteren har kontroll over teksten. Gjennom kronikker kan man uttrykke seg faglig på premisser man selv setter. Det forutsetter naturligvis at man har noe viktig og fortelle og at noen vil trykke det endelige manuskriptet.

Kronikker kan få stor oppmerksomhet både i media og i berørte fagmiljøer. Mange husker sikkert kronikkene i Aftenposten sommeren 2008 om sammenheng mellom provosert abort og rusmisbruk skrevet av professor Willy Pedersen fra UiO. Budskapet ble møtt av motsvar fra avdelingsdirektør ved Folkehelseinstituttet Preben Aavitsland. Han stilte spørsmål ved slutningene Pedersen hadde trukket vedrørende årsaks- og virkningsforhold. Gjennom flere innlegg fikk allmennheten innsyn i en faglig kausalitetsdebatt som dreide seg om mulige ettervirkninger etter provosert abort. Innleggene fra disse fagfolkene er gode eksempler på hvordan en avansert metodediskusjon, som vanligvis foregår i forskningsfora, kan fremstilles i en form og med begreper som gjør den interessant for folk flest.

\section{$>$ KRONIKKER FRA SYKEPLEIER- HVERDAGEN}

Sykepleiere arbeider i svært ulike posisjoner i samfunnet. Mens mange arbeider med pasienter, og hjelper sine faste pasienter over lengre tid, jobber andre med organisering og administrasjon av kompliserte institusjoner med store budsjetter. Til daglig står sykepleierne i situasjoner og tar valg som andre ville kunne være interessert i å få innsyn i. Ved å gi allmennheten innsyn, kan det skapes interesse for viktige problemstillinger som mange kanskje ikke har tenkt over at eksiterer. Hvis man mener at sykepleiekompetanse er viktig for samfunnet, er kronikk et format hvor man kan gi gode eksempler og vise hvordan kompetanse kan gjøre en forskjell.

\section{$>$ HVORDAN SKRIVE OG STRUKTURERE EN GOD KRONIKK?}

Det virker som om det ikke finnes mye litteratur på dette temaet. For interesserte lesere kan nettsiden til Magne Lindholm anbefales (se litteraturlisten). Hans beskrivelse av hvordan skrive kronikk har mange nyttige tips som er verd å lese. Det er også konkrete tips å hente ved å google «op-ed». Rådene i denne artikkelen er i hovedsak hentet ut fra disse kildene, men også egen erfaring med å skrive og med å redigere andres kronikker.

Oppbygging av en artikkel er nesten det motsatte av vanlige akademiske arbeider. I sistnevnte arbeider er det vanlig at man presenter ulike argumenter og drøfter disse for å konkludere til slutt. Kronikken starter ofte med konklusjonen og etterfølges av argumenter, fakta og beskrivelse som bygger opp om det man påsto. Det kan være lurt å dobbeltsjekke fakta. Et råd hvis man sitter fast i skrivingen er ofte å flytte den avsluttende konklusjonen foran i manuskriptet. Bruk ulike troverdige kilder og gjerne uttalelser fra tredjeperson. Argumentasjonen og diskusjonen er den delen som gjerne tar størst plass. Til slutt munner kronikkene ofte ut i en klar anbefaling eller oppfordring.

\section{$>$ KLAR MENING}

En spenstig konklusjon innledningsvis trigger leseren til å lese videre. En forutsetning er at man fremsetter klare meninger om én sak. Hvis man synes det er vanskelig å uttrykke seg klart i frykt for å få motinnlegg, er trolig ikke kronikken den rette formen å ytre seg på for forfatteren. En klar fallgruve er at man ønsker å si mye om flere saker når man først er i gang med å skrive. Rydd heller opp i de ulike problemstil- 
lingene og lag flere kronikker som kan sendes til ulike aviser og tidsskrifter.

\section{$>$ AKTUALITET}

Problemstillingen som kronikken handler om må ha aktualitet for mange av leserne. Aktualitet kan knyttes til bestemte dager, for eksempel tidspunkt for et jubileum, dagen for lansering av en stortingsmelding, eller sommeren hvis kronikken handler om fagkompetanse i hjemmetjenestene under ferieavvikling. Hvis aktualiteten for leserne ikke er åpenbar, må forfatteren sørge for dette innledningsvis. De første linjene avgjør om leserne blar om til neste side eller får lyst til å lese videre. En ekstra oppmerksomhet bør derfor vies starten på teksten.

\section{> KORTE SETNINGER OG KLARE BEGREPER}

Et råd som ofte gis er å skrive korte setninger. Når man nærmer seg slutten på skrivingen, bør man gå igjennom å lete etter unødige ord og bisetninger som gjentar det man allerede har sag. Lange setninger kan også ofte deles opp på en ny måte. Kronikker inneholder ikke fremmedord og vanligvis ikke fagspråk. Hvis et fagbegrep unntaksvis brukes, bør det i så fall etterfølges av en enkel og grei forklaring. Det kan være en lærerik erfaring for forfatteren å beskrive innarbeidede fagbegreper med vanlige norske ord. Man tvinges til å tenke igjennom hva som egentlig ligger i begrepene - begreper man kanskje bruker daglig med største selvfølgelighet.

\section{> FØLG KRONIKKVEILEDNINGEN}

Noen avsier og tidsskrifter har en liten beskrivelse av hvordan kronikken skal utformes og hvor den skal sendes. En fare er at man skriver for langt. Hvis ikke avisen eller tidsskriftet man ønsker å sende kronikken til har oppgitt ønsket lengde bør man sjekke lengden på det de har publisert. Aftenposten opererer for eksempel med en normallengde på 6500 tegn inkludert mellomrom.

Landsdekkende aviser får gjerne tilsendt flere kronikker hver dag. I praksis blir de fleste avslått. Når man sender inn en kronikk og ber avisen tar den inn, bør man derfor ha jobbet grundig med teksten. I lokalaviser er ofte det lettere å få inn en kronikk. Hvis man $\emptyset n$ sker teksten publisert i en landsdekkende avis må man forvente større konkurranse. Dette innebærer høyere krav til aktualitet, originalitet, klare meninger og god språkføring. Få gjerne kollegaer eller venner til å lese igjennom og kommentere utkastet før det sendes inn. Da har man en fin anledning til å luke bort feil, rette opp uklart budskap og avdekke svakheter ved argumentasjonen man ikke selv har sett.

\section{> NÅR KRONIKKEN SENDES INN}

Når manuskriptet sendes til avisen eller fagtidsskriftet kan det være lurt å foreslå en overskrift. Denne bør være kort, slående med en klar sammenheng til poengene som kommer i begynnelsen av teksten. Men, vær klar over at avisen eller tidsskriftet bestemmer overskriften. Jo mer slående og til poenget forslaget ditt er, dess større er sjansen for at der er din versjon som kommer på trykk.

Når teksten sendes inn som et vedlegg i en e-post kan det være lurt å beskrive kort hva kronikken handler om og dens aktualitet. Dette gir kronikkredaktøren et første inntrykk av teksten vedkommende skal vurdere.

Hvis du sender teksten til kronikkredaksjonen tidlig om morgenen, kan det være lurt å ta en telefon til redaksjonen senere på dagen for å få bekreftelse på at de har mottatt den. Slik får du en foreløpig tilbakemelding på om de har lest den. Uansett gir det en mulighet for forfatteren til å presentere seg.

Den relativt høye andelen sykepleiere i helsevesenet, skulle tilsi at sykepleiere relativt hyppig var representert blant kronikkforfattere med helsebakgrunn. Her har forfatteren dessverre ingen empiri, men sitter med en oppfatning om at yrkesgruppen ikke har vært representert med sin andel. Dette bør være en utfordring for sykepleiere!

\section{LITTERATUR}

1. Lindholm M. http://home.hio.no/ magneli/tips_og_lenker/ hvordan_skrive_kronikk.html

2. Nylenna, M. Publisere \& presentere. Oslo: Gyldendal Norsk Forlag AS; 2008. 